EXEMPLARIa Classica

Journal of Classical Philology

21, 2017, pp. $125-148$

ISSN 1699-3225

\title{
GIOVANNI DE MATOCIIS AND THE CODEX ORATORIANVS OF THE DE VIRIS ILLVSTRIBVS VRBIS ROMAE
}

\author{
JUSTIN STOVER \\ University of Edinburgh \\ justin.stover@ed.ac.uk
}

GEORge WoudHuYsen All Souls College, University of Oxford george.woudhuysen@all-souls.ox.ac.uk

\begin{abstract}
SuMMARY
One of the most curious manuscripts of the De uiris illustribus is Biblioteca dei Girolamini, XL pil. VI, no. XIII. This manuscript has been thought either to go back to the early Veronese humanist Giovanni de Matociis, or to contain authentic ancient information. We demonstrate that the manuscript has nothing to do with Matoci, but is closely linked to Giacomo Filippo Foresti, a latefifteenth-century historian. Its chief feature of interest is that it shares some readings with another branch of the tradition of the DVI, the Corpus Aurelianum, thus providing new evidence for the circulation of that text.
\end{abstract}

KEY WORDS

De uiris illustribus; manuscripts; humanism.
RESUMEN

Uno de los manuscritos del De uiris illustribus (DVI) más curiosos es Nápoles, Biblioteca dei Girolamini, XL pil. VI, no. XIII. Entre los rasgos que se han asociado a este manuscrito se encuentran dos: que se remonta al temprano humanista veronés, Giovanni de Matociis, y que contiene información antigua auténtica. Demostramos que el manuscrito no tiene nada que ver con Matoci, sino que está estrechamente ligado a Giacomo Filippo Foresti, un historiador del fines del siglo $\mathrm{XV}$. El principal interés de este manuscrito es que comparte algunas lecturas con otra rama de la tradición del DVI, el Corpus Aurelianum, así proporcionando nuevas pruebas para la circulación de ese texto.

Palabras Clave

De uiris illustribus; manuscritos; humanismo.

Fecha de recepción: 23/05/2017

Fecha de aceptación y versión final: 03/10/2017 


\section{Introduction: Giovanni Matoci and the De ViRis ilLVStribvS}

In around 1330, the mansionarius of the cathedral of Verona, one Giovanni de Matociis (ob. 1337), produced one of the first monuments of humanist critical scholarship. ${ }^{1}$ In his Breuis adnotatio de duobus Pliniis he successfully distinguished, for the first time since antiquity, the author of the Historia naturalis from the (relentless) correspondent of the emperor Trajan. ${ }^{2}$ Amongst the works of the younger Pliny, he listed a Liber uirorum illustrium a Proca rege Albanorum usque ad Cleopatram in nonaginta octo capitulis secundum ipsorum uirorum numerum in quo uitas ipsorum et merita mirabili et aperta breuitate describit ('The book of famous men from Proca, king of the Albans, up to Cleopatra in ninetyeight chapters, in accord with the number of those men themselves, in which he describes their lives and deeds with wonderfully clear concision'). ${ }^{3}$ This can be nothing other than the text commonly known today as the $D e$ uiris illustribus urbis Romae (henceforth DVI), a scrappy biographical dictionary of regal and Republican history, which the manuscripts do indeed attribute to the younger Pliny, and for which Matoci is our first witness after antiquity. ${ }^{4}$ Unfortunately, the manuscripts which transmit this text all come from at least the generation after Matoci - the earliest datable was written a little before 1376 - and have only seventy-seven chapters, starting indeed with Proca but concluding with an imperfect account of Pompey the Great. ${ }^{5}$ These witnesses can be divided into two broad families (called C and D): one (C) ends mid-sentence in the biography of Pompey and the other (D) with

${ }^{1}$ On Matoci and his discovery, see in general M. Zabbia, "Matociis, Giovanni de", Dizionario biografico degli Italiani vol. 72, 2008. Online at http://www.treccani.it/enciclopedia/ giovanni-de-matociis_\%28Dizionario-Biografico\%29/.

${ }^{2}$ Adnotatio, ed. E. T. Merrill, “On the Eight Book Tradition of Pliny's Letters in Verona”, CPh 5, 1910, 175-88.

${ }^{3}$ Merrill, “On the Eight Book Tradition”, 188.

${ }^{4}$ For the manuscript attribution to Pliny, see W. K. Sherwin, "The Title and Manuscript Tradition of the De viris illustribus", RhM 102, 1969, 284-6. The most recent edition is P. M. Martin, ed., trans., Les Hommes illustres de la ville de Rome. Paris: Belles Lettres, 2016, which replaces the inadequate texts of F. Pichlmayr, ed., Sexti Aurelii Victoris liber de caesaribus, Leipzig: Teubner, 1911 (R. Gruendel, rev. ed. 1970), and W. K. Sherwin, ed., trans., Deeds of Famous Men (De viris illustribus), Norman, OK: University of Oklahoma Press, 1973. The tradition is discussed by R. J. Tarrant, M. D. Reeve, “De Viris Illustribus”, in L. D. Reynolds, ed., Texts and Transmission: A Survey of the Latin Classics, Oxford: Clarendon Press, 1983, 149-53.

${ }^{5}$ Pavia, Bibl. univ. 68, which has an ownership date from that year; it is not fifteenthcentury, as Martin, Les Hommes illustres, 58, suggests. It was first uncovered by G. Ferrara, "Il cod. Ticin. 68 ed il De vi. illustribus dello pseudo-Plinio", RFIC 36, 1908, 508-17. BAV lat. 1917 (https://digi.vatlib.it/mss/detail/Vat.lat.1917) was not written in 1328 as Sherwin and Martin thought, but rather in 1392 as demonstrated by G. Billanovich, "Il Petrarca e gli storici latini", in G. Bernadoni Trezzini, ed., Tra latino e volgare: per Carlo Dionisotti, Padua: Editrice Antenore, 1974, I, 83-4. 
an obviously tacked-on concluding paragraph. ${ }^{6}$ This suggests that they both descend from an archetype which had suffered physical damage at its end, and that makes the question of what exactly Matoci saw rather intriguing. Did he derive the number of chapters and scope from a capitulatio (table of contents) or from actual acquaintance with the whole text? The fact that no capitulatio containing a list of all ninety-eight chapters has been transmitted is a strong indication that he had indeed made his calculation by actually reading the text in an undamaged state - something also suggested by his comment on its style. ${ }^{7}$ Evidently, Matoci's manuscript did not survive.

Fortunately, we have some idea of the scope of the 'original' work because a completely separate branch of the tradition of the $D V I$ survived in a curious late-antique compilation, the Corpus Aurelianum or $C A$ (more commonly, but less correctly, called the Corpus tripertitum). ${ }^{8}$ This is a two-part compilation of three works, which together trace the history of Rome from legendary Alban days to A.D. 360. The first of these is the socalled Origo gentis Romanae (Momigliano was probably correct that this was in fact the title of the whole $C A$, not the first work alone), a fantastical antiquarian tour d'horizon, supposedly derived from an exotic menagerie of fragmentary Roman historians: Cincius Egnatius, Verrius Flaccus, Tubero, Veratius, the Annales pontificum, and other such reputable names. ${ }^{9}$ The last is the Historia abbreviata of Sextus Aurelius Victor, the De Caesaribus of handbooks. In between these - the bridge spanning myth and imperial history - is a version of the $D V I$ in eighty-four chapters, without Proca at the beginning and chapter sixteen in the middle, but with nine additional chapters at the end, concluding with a brief life of Cleopatra. ${ }^{10}$ The text of

${ }^{6}$ See Tarrant and Reeve, "De Viris Illustribus", 152.

${ }^{7}$ There is a capitulatio at the beginning of Pavia 68, but that only contains a list of the seventy-seven chapters found in the manuscript, followed by an intriguing C. Jullius Cesar and De phenice avis, with the marginal note ex nāli Jstoria (ex naturali historia). After the text, it does include two excerpts from Pliny the Elder (NH 7.91-2 and 10.3-5). Ferrara, "Il cod. Ticin. 68", 517 thought that this was evidence of a longer capitulatio, but his suggestion rests upon the courageous assumption that De phenice avis actually conceals the name Octavianus. It hardly requires imagination, however, to supplement an account of Pompey the Great with an anecdote about Caesar, while Egypt (where we left Pompey) is mentioned in the passage from which the account of the phoenix has been excerpted. Moreover, these two passages of Pliny circulated as self-standing anecdotes in a number of fifteenth-century manuscripts, see A. Borst, Das Buch der Naturgeschichte: Plinius und seine Leser im Zeitalter des Pergaments, Heidelberg: Winter, 1994, 314, nn. 54-5.

${ }^{8}$ This compilation has traditionally been called the Corpus tripertitum because it contains three separate texts. The manuscripts, however, explicitly divide the text into two parts and also give the name of Aurelius Victor, probably mistakenly, at the beginning of the whole corpus (see Martin, Les Hommes illustres, xxix), so the term Corpus Aurelianum more accurately reflects the state of the transmitted text.

9 A. Momigliano, "Some Observations on the 'Origo Gentis Romanae", JRS 48, 1958, 58.

${ }^{10}$ All three texts are available in Pichlmayr, Sexti Aurelii Victoris liber, but the texts 
the $D V I$ is obviously superior at many points to that found in the seventyseven chapter version, but it also betrays the intervention of one or several late-antique or medieval editors. ${ }^{11}$ The Corpus Aurelianum has a very shadowy history: there are only two mid-fifteenth-century manuscripts and it did not appear in print until Schott's edition, published at Antwerp in $1579 .{ }^{12}$ Matoci's version seems to lie somewhere between the two independent branches of the tradition: with Proca at the start (unlike the $C A$ ), but also with Cleopatra at the end (unlike the seventy-seven chapter version). Although if we combined the version of the $D V I$ transmitted in the $C A$ with that which we have independently, we would end up with a work which had the same beginning and end as that which Matoci read, no combination or mutation of the two versions can give us a continuous series of 98 lives. The most elegant explanation of these conflicting data is that Matoci had access to an ancient manuscript - preserved at the chapter library of Verona, like so many other unique Roman codices - which contained a text which in some way stands behind both extant versions of the $D V I .^{13}$

\section{A Curious Manuscript}

In 1916, Attilio Barriera found what he thought might be a solution to this conundrum. In the Oratorian Library in Naples, the Biblioteca dei Girolamini, he had discovered what he thought was an early-fifteenth-century manuscript of the $D V I$ (cod. XL, pil. VI, no. XIII) in a version preserved nowhere else (Pichlmayr had included it in his baffling list of codices non examinati). ${ }^{14}$ This was quite unlike other versions of the $D V I$, for it began with Proca, extended beyond the life of Pompey, and (compared with the

of the OGR in J.-C. Richard, ed., trans., Pseudo-Aurélius Victor. Les Origines du Peuple Romain, Paris: Belles Lettres, 1985, and the Historia abbreviata in F. Dufraigne, ed., trans., Aurélius Victor. Livre des Césars, Paris: Belles Lettres, 1975, are superior. M. Festy, “À propos du Corpus Aurelianum: à la recherche des leçons du Codex Metelli perdu”, Pallas 41, 1994, 115-6 argues that chapter 16 was originally part of the Corpus Aurelianum, but omitted in the archetype of the surviving manuscripts; the evidence he marshals does not quite support this conclusion.

${ }^{11}$ The consensus view is that the text of the $D V I$ has been interpolated from the Historia miscella of Landolfus Sagax (s. XI), see, e.g., Momigliano, "Some Observations", 59-60. This thesis is rather more fragile than its adherents realise.

${ }^{12}$ A. Schott, ed., Sexti Aurelii Victoris historiae Romanae breviarium, Antwerp, 1579. He had already published an edition of the DVI two years earlier (A. Schott, ed., De viris illustribus urbis Romae liber, Douai, 1577), which had the additional chapters of the DVI in the $C A$.

${ }^{13}$ The ancient manuscripts in Verona can be conveniently surveyed in E.A. Lowe, Codices Latini Antiquiores IV, Oxford: Clarendon Press, 1947.

${ }^{14}$ A. Barriera, "Il codice XL della Biblioteca Oratoriana di Napoli e il 'de viris illustribus urbis Romae' d'incerto autore”, Athenaeum 4.4, 1916, 434-53; Pichlmayr, Sexti Aurelii Victoris liber, xvii; see also the entry in E. Mandarini, I codici manoscritti della Biblioteca Oratoriana di Napoli, Naples: A. \& S. Festa, 1897, 65-6. 
other transmitted versions of the $D V I$ ) had many variants and additions, along with some omissions. Because of its poor state of preservation, the exact scope of the text could not be recovered, but Barriera arrived at a total of ninety-four chapters and suggested that it might have been related to Matoci's ninety-eight chapter version. ${ }^{15} \mathrm{He}$ raised the exciting possibility that some of the additional material found in the manuscript was authentically ancient, and that taken as a whole this new version of the $D V I$ was a previously undiscovered ancient text. The scholarly world, understandably preoccupied at the time, reacted in a fashion which can only be described as somnolent. Barriera's bold and interesting hypothesis received no attention for a full century, until Martin's 2016 edition of the DVI, while even the manuscript from which he worked was not re-examined until the 1960s. ${ }^{16}$ In 1969, when again much of the world was otherwise occupied, W.K. Sherwin published a laconic article on its contents, arguing for a new reconstruction which would bring the chapter total up to ninety eight. This conclusion led him to the theory that it was a descendant of Matoci's copy of the work which had just lost the life of Cleopatra and subsequently been renumbered. ${ }^{17}$ The fullest account of the manuscript, however, can be found in Martin's Budé edition, where he systematically includes it under the siglum ' $\mathrm{z}$ ', and transcribes most of its additions in the apparatus criticus. He does not come to a definitive judgement of the antiquity of the material in the Naples manuscript, though he does assign it a place in his stemma codicum connected to Matoci, one of two pieces of evidence for a putative third branch of the transmission of the $D V I^{18}$

All this makes the Naples manuscript sound 'très intéressant', as Martin puts it, or 'a curious manuscript', in the description of Tarrant and Reeve (effusive praise from exacting judges). ${ }^{19}$ That impression is only heightened by an intriguing hint in Barriera which has never been followed up. The $D V I$ only occupies half of the codex, the rest comprising an imperial history down to at least the late-third century, made up of extracts (according to Barriera) from the so-called Epitome de Caesaribus, from Aurelius Victor, Suetonius, the Historia Augusta, and Eutropius. ${ }^{20}$ At first blush, this seems extraordinarily significant, because in the Corpus Aurelianum the DVI is

${ }^{15}$ Barriera, "Il codice XL", 452.

${ }^{16}$ Martin, Les Hommes illustres, xxxvii-xxxix.

${ }^{17}$ W. K. Sherwin, “Johannes Mansionarius, Neapolitanus XL Pil. VI No XIII in $8^{\circ}$ and the de Viris Illustribus", Hermes 97.4, 1969, 503-5.

${ }^{18}$ Martin, Les Hommes illustres, lxxv for the stemma; discussion on xxxix. In what follows, we quote Barriera's superior transcription wherever possible, and Martin's where Barriera is lacking. In both cases, however, we only present the text as printed, i.e. uncorrected and unedited.

${ }^{19}$ Martin, Les Hommes illustres, lxvi; Tarrant and Reeve, “De Viris Illustribus”, 152 n. 20.

${ }^{20}$ Barriera, "Il codice XL", 436-7. 
transmitted with an imperial history (Aurelius Victor), and Matoci's magnum opus was nothing other than an Historia imperialis. ${ }^{21}$ The manuscript looks as if it could either have undiscovered ancient material about the emperors, or conversely descend from Matoci's desk, the combination of a DVI and an imperial history suggesting a direct connection to him. Only an examination of the imperial portion of the manuscript could resolve the issue.

Unfortunately, when we set out to do that, we found the seasons not propitious to this sort of endeavour. The Biblioteca dei Girolamini has fallen on hard times and has been closed as part of ongoing police investigations, since it was discovered in 2012 that its then chief librarian, as a brief interlude in an allegedly successful career as a forger of early-modern books, had in his one-year tenure left the collections in a shambles and allegedly ransacked them for saleable or tradable items. ${ }^{22}$ Our approaches to the library were met with silence; a colleague who attempted to gain access through the front door was unable to; the Oratorians in Oxford could provide no information or contacts; friends and colleagues who had used the collection in the past were not able to provide an entrée. Fortunately, the catalogue of the Institut de recherche et d'histoire des textes, part of the CNRS, suggested that they possessed a microfiche of some portions of the manuscript, which could be consulted in situ. Of the excerpts which we were able to consult in Paris, there was indeed some overlap of coverage with the Historia imperialis of Matoci. ${ }^{23}$ What there was not was any significant overlap of phrasing. The treatment of Carus, Carinus, and Numerian provides a good example. The same events are often related in similar language - there are after all hardly any sources for these emperors - but there are significant variations in phrasing (TABLE 1).

${ }^{21}$ Lamentably still unedited, this work is partially extant in three manuscripts: Verona, Biblioteca Capitolare CCIV, Rome, Biblioteca Vallicelliana Cod. D. 13, and BAV Chig. lat. I. VII. 259. We have consulted a microfilm of the last, to which reference is made in what follows. R. Weiss, "Ausonius in the Fourteenth Century", in R.R. Bolgar, ed., Classical Influences on European Culture A.D. 500-1500, Cambridge: Cambridge University Press, 1971, 68 n. 8 cites the opinion of Augusto Campana that this was Matoci's fair copy of the text.

${ }_{22}^{2}$ The story is well told by N. Schmidle, "A Very Rare Book". New Yorker 12/16/2013. Accessed online http://www.newyorker.com/magazine/2013/12/16/a-very-rare-book [10/08/2016].

${ }^{23}$ We would like to thank the staff of the IRHT for their great help in this matter. Unfortunately, not all folio numbers were visible and so we have had to cite some passages without foliation. 


\begin{tabular}{|c|c|}
\hline $\begin{array}{l}\text { Matoci, Historia imperialis, Chig. Lat. I } \\
\text { VII } 259 \text { f. } 29 \mathrm{va}\end{array}$ & Naples, Biblioteca dei Girolamini, XL \\
\hline $\begin{array}{l}\text { Nam Carinum filium suum natu maiorem } \\
\text { ad Gallias tuendas cum electo exercitu } \\
\text { misit. Constantium uero pro tuendo } \\
\text { Illirico eisdem partibus praesidem fecit. } \\
\text { Filium uero Numerianum Cesarem secum } \\
\text { ad bellum Parthicum et Persicum duxit. } \\
\text { Hic, dum Sarmatas subiugasset, uenit ad } \\
\text { Persas. Sed prius Mesopotamiam cepit } \\
\text { et, ciuitatibus Persarum ferro et igne } \\
\text { uastatis, una cum Arrio Valerio Apro } \\
\text { praefecto praetorii usque ad Thesifontem } \\
\text { urbem uincendo uenit. Ubi, dum castra } \\
\text { posuisset ut ciuitatem obsideret, subito } \\
\text { quadam die, ingentibus nubium et } \\
\text { tempestatum ac fulminum procellis } \\
\text { exortis, dum Carus esset in papilione } \\
\text { et aliquantulum egrotaret, fulgore ictus } \\
\text { interiit, quamquam Iunius Calphurnius } \\
\text { scribat non Carum fulmine occisum sed } \\
\text { morbo defunctum. }\end{array}$ & $\begin{array}{l}\text { Interea Carinus [sic for -um] ad Parthos } \\
\text { proficiscens Carus in Yllirico Gallia } \\
\text { Italia reliquerat et omnibus se sceleribus } \\
\text { inquinauit, plurimos innoxios fictis } \\
\text { criminibus occidit, nobilia matrimonia } \\
\text { corrupit, condiscipulis qui usque [ut uid. } \\
\text { in cod.] in auditorio uerbi fatigatione } \\
\text { taxauerunt perniciosus fuit, atque } \\
\text { omnibus hominibus inuisus, non multo } \\
\text { post penam luit; nam de Perside uictor } \\
\text { exercitus rediens, Carum patrem fulmine } \\
\text { ictum et Numerianum insidiis prodidisset. }\end{array}$ \\
\hline
\end{tabular}

\section{Table 1}

Matoci's careful summary is synthetic, although dependent above all on the Historia Augusta, a text whose most important manuscript he had in his hands and covered with his scribbles (now BAV Pal. lat. 899). ${ }^{24}$ He has rephrased his sources and turned them into an impressively concise summary of what was known. As not infrequently, he cites his source's (alleged) sources (Iunius Calpurnius is in Carus, Carinus et Numerianus 8.4, and Matoci has condensed a letter he supposedly sent). ${ }^{25}$ The Naples text, however, essentially reproduces Eutropius' account (9.19) verbatim. ${ }^{26}$ Other passages show exactly the same divergence in style and working methods, and there is no reason to think that the Naples manuscript, in its imperial portion at least, has any relationship to Matoci, or that its author had any knowledge at all of his Historia imperialis.

${ }^{24}$ See P. K. Marshall, "Scriptores Historiae Augustae”, in L. D. Reynolds, ed., Texts and Transmission: A Survey of the Latin Classics, Oxford: Clarendon Press, 1983, 355.

${ }^{25}$ E. Hohl, ed., Ch. Samberger, W. Seyfarth, corr., Scriptores Historiae Augustae, Leipzig: Teubner, 1965, II, 239.

${ }^{26}$ C. Santini, ed., Eutropii Breviarium ab Urbe condita, Leipzig and Stuttgart: Teubner, 1979, 62 . 


\section{Giacomo FiLippo Foresti}

If it has no connection Matoci, what is the origin of the Naples manuscript? In particular where does all the extra material which it provides come from and is it really ancient? A good passage on which to test this proposition is an amusing anecdote about the life of the Republican-era potentate Lucullus, which is found in the Naples manuscript (and only there) as a supplement to $D V I 74$ :

\section{Naples, Biblioteca dei Girolamini, XL (Martin, Les Hommes illustres, 80 = Barriera, "Il codice XL", 450-451):}

Demum cum sponte sese a re publica abdicasset, reliquum uitae suae ad otium litteris contulit et ad tantas se conuertit delicias ut inter ornatos regum conuiuas Luculli (sic) dinumerarentur et quadam die Pompeius et Cicero hoc audientes Lucullum ex otio in foro sedentem conuenerunt et eo ex more salutato Cicero: uolumus, inquit, o Luculle apud te coenare hodie, hac condicione ut nihil noui nostra causa parari iubeas; quod Lucullus recusauit sed in posterum diem parari conuiuium postulauit. Illi autem nolle omnino differre neque secreto familiares potestatem alloquendi concedere. Post multa uero hanc illi tantum gratiam postremo praestitere ut illis audientibus uni ex domesticis diceret: hodie in Apolline coenabimus. Quo audito famuli confestim intellexerunt quali ornatu quoue sumptu conficiendum esset conuiuium. Nam sic nominatim conuiuia disponebat.

As Barriera noted, this story is found solely in Plutarch and occurs in no ancient Latin source. ${ }^{27}$ At first sight, this offers a tantalising possibility: the Naples manuscript appears to have authentic ancient information which we can corroborate from elsewhere, but which was not otherwise available in Latin. On close inspection, unfortunately, this proves to be a mirage: the information is authentic and it is ancient, but it is also derived directly from Plutarch. The anecdote has an extremely close verbal correspondence to the 1416 translation of the Vita Luculli by Leonardo Giustinian (TABLE 2). ${ }^{28}$

${ }_{27}$ Plutarch, Lucullus 41.3-6 (K. Ziegler, ed., Plutarchi vitae parallelae, I.1, Leipzig: Teubner, 1969).

${ }^{28}$ Widely disseminated, it is extant in some eighty manuscripts, and reprinted in a number of editions; cf. M. Pade, The Reception of Plutarch's Lives in Fifteenth-Century Italy. 2 vols., Copenhagen: Museum Tusculanum Press, 2007, II, 122; on the date of the translation, see Pade, The Reception, I, 202-7. 

Plutarch, Lucullus 41 (trans. Giustinian,
from ed. Basel 1535, f. 213v):

Itaque cum totam iam urbem harum rerum crebra fama peruaderet, Lucullum tunc fortè per ocium in foro sedentem Pompeius Ciceroque conuenere. . . Cicero itaque salutato Lucullo, Nunquid disputare de philosophia luberet, rogabat; cumque ille respondisset lubere maxime, \& adesse ultro etiam iussisset, Volumus, inquit, apud te coenare hodie, fed ea conditione, ut nil noui nostri causa parari iubeas. Subrecusabat, id Lucullus, \& in posterum diem differri conuiuium postulabat: illi uero neque differre, neque alloquendi secretò familiares suos facultatem sibi facere uoluere, ne aliud domi parari iuberet conuiuium. Hanc tamen ei postremo ueniam præstitere, ut ipsis audientibus cuidam ex familiaribus suis id solum diceret, In Apolline coenabitur hodie; ea sola uoce fefellit eos. Id enim erat unum ex maximis eius coenaculis eo nomine appellatum. Singulis enim (ut uidetur) coenaculis, \& conuiuij precium, \& splendor apparatus definitus erat. Quamobrem famuli audito loci nomine, confestim intelligebant quantis sumptibus, quali ornatu, quoue ordine conficiendum esset conuiuium. Consueuerat autem precij quinquaginta millium in Apolline coena parari. Quæ cum sic eo quoque die acta fuisset, mirabatur stupore quodam Pompeius in tanta epularum abundantia celeritatem apparatus.
Naples, Biblioteca dei Girolamini, XL

... Pompeius et Cicero hoc audientes Lucullum ex otio in foro sedentem conuenerunt et eo ex more salutato Cicero:

uolumus, inquit, o Luculle apud te coenare hodie, hac condicione ut nihil noui nostra causa parari iubeas; quod Lucullus recusauit sed in posterum diem parari conuiuium postulauit. Illi autem nolle omnino differre neque secreto familiares potestatem alloquendi concedere.

Post multa uero hanc illi tantum gratiam postremo praestitere ut illis audientibus uni ex domesticis diceret: hodie in Apolline coenabimus.

Quo audito famuli confestim intellexerunt quali ornate quoue sumptu conficiendum esset conuiuium. Nam sic nominatim conuiuia disponebat.

\section{Table 2}

Giustinian's Plutarch is not the only humanist source which has left traces in the Naples manuscript. After the life of Coriolanus (DVI 19), it adds an account of Veturia, Coriolanus' mother according to one tradition:

De Veturia matre Coriolani. Veturia, praedicti Coriolani mater, filium, quem legatorum maiestas et pontificum reuerentia auertere $a b$ obsidione patriae nequiuerant, ipsa ab ira retraxit: ob cuius mulieris benefitium ne ciuitas ingratitudine argueretur ex S.C. ad perpetuam rei memoriam eo in loco templum cum ara fortunae muliebri constitutum 
est, et tunc sancitum est ut mulieribus assurgerent homines et in uia eis cederent, quod nunc apud nobiles seruatur, et [ut] eis liceret uti auro et purpurea ueste, aureisque fibulis et armillis et haereditates quorumcumque consanguineorum et parentum consequi possent. ${ }^{29}$

The source of this story is none other than the De claris mulieribus of Boccaccio (completed in 1374):

Ex quo secutum est ne glorie mulieris ingratitudine detraheretur, ut ex senatus consulto eo in loco in quo Veturia filii iram molliuerat, templum ad eius rei memoriam perpetuam, et ara Fortunae muliebri ex cocto construeretur lapide ... sanxitque ut pretereuntibus mulieribus, quibus nullus uel minimus usque ad illam etatem a uiris prestabatur honor, et assurgerent homines et uia cederent; quod nostra in patria ritue ueteri seruatur huc usque. Et quia eis liceret uti auro et purpurea ueste, aureisque fibulis et armillis, Nec desunt qui asserant eodem ex senatus consulto adiectum ut quod ante non licebat, possent haereditates consequi quoruncumque. ${ }^{30}$

Hence, whatever the exact nature of the compilation in the Naples manuscript, its additional material is a product of the humanist scholarship of the fourteenth and fifteenth centuries: we can be certain that it has no relationship to anything that Matoci could have known in 1330, and so its text of the $D V I$ bears no relation to what he saw. Rarely has good information about Roman history been more disappointing to ancient historians.

All this suggests that if we want to understand the Naples, we must look in the humanist milieu of the fifteenth century. That leads us to a remarkable and rather neglected historian: Giacomo Filippo Foresti (1434-1520). Foresti's Supplementum chronicarum, a world history from the beginning to his own day, was first published at Venice in 1483, then printed at least four more times before 1500, and swiftly translated into Italian. ${ }^{31}$ Foresti made many minor and some very substantial changes to the text of his history over the course of these printings, but for present purposes, the editions which are most important are those issued at Venice in 1483 and at Brescia in 1485. Comparison of these two with the text of the Naples manuscript shows that they have a very close relationship, as these versions of the history of Diocletian demonstrate (TABLE 3).

${ }^{29}$ Barriera, "Il codice XL", 449 = Martin, Les Hommes illustres, 25.

${ }^{30}$ Boccaccio, On Famous Women 55.11 (V. Brown, ed., trans., Giovanni Boccaccio. Famous Women, Cambridge MA: Harvard University Press, 2001, 228-9).

${ }^{31}$ On Foresti and his Supplementum, see in general L. M. Fratini, "Forèsti, Giacomo Filippo." Dizionario biografico degli Italiani vol. 48, 1997. Online at http://www.treccani. it/enciclopedia/giacomo-filippo-foresti_\%28Dizionario-Biografico\%29/. Printings: Venice, 1483 (USTC 994083); Brescia, 1485 (994082); Venice, 1486 (994081); Venice, 1490 (994080); Venice, 1492 (994079). Italian translation: Venice, 1491 (994090). 


\begin{tabular}{|c|c|c|}
\hline $\begin{array}{l}\text { Foresti, Supplementum } \\
\text { chronicarum (Venice, } \\
\text { 1483), lib. VIII, anno } \\
\text { mundi 5485, Part II, f. } \\
34 \mathrm{v}\end{array}$ & $\begin{array}{l}\text { Foresti, Supplementum } \\
\text { chronicarum (Brescia, } \\
\text { 1485), lib. VIII, anno } \\
\text { mundi } 5485, \text { f. } 173 \mathrm{v}\end{array}$ & $\begin{array}{l}\text { Naples, Biblioteca dei } \\
\text { Girolamini, XL (p. } 154 \\
\text { secundum tabulam). }\end{array}$ \\
\hline $\begin{array}{l}\text { Dioclitianus Dalmatheus } \\
\text { 31us Romanorum impera- } \\
\text { tor } 2 \text { o anno } 265 \text { Olympiadis } \\
\text { Augustus declaratus impe- } \\
\text { rauit annis xx. uir certe pro- } \\
\text { bus ac prudens, qui scribe fi- } \\
\text { lius apud Salonem nunc Spa- } \\
\text { latum natus populi, senatu- } \\
\text { sque ac militum consensu } \\
\text { imperator electus fuit, qui } \\
\text { statim ut imperator factus } \\
\text { est Aprum qui Numeria- } \\
\text { num interfecerat manu } \\
\text { propria occidit. Verum post } \\
\text { aliquot menses cum multa } \\
\text { bella prospere gessisset im- } \\
\text { minentibus bellorum turbi- } \\
\text { nibus ac solus resistere non } \\
\text { posset Maximianum cogno- } \\
\text { mento Herculeum Caesarem } \\
\text { primo, postea Augustum et } \\
\text { imperii consortem decla- } \\
\text { rauit. Qui agrestes in Gallia } \\
\text { facile compescuit, et pacem } \\
\text { Galliis redidit. Quarto dein- } \\
\text { de imperii sui anno, cum } \\
\text { quidam Carausius sumpta } \\
\text { purpura Britanniam insu- } \\
\text { lam occupasset, et Narseus } \\
\text { alter orienti bellum intu- } \\
\text { lisset, nonnullique alii infe- } \\
\text { starent Aphricam et Egyp- } \\
\text { tum Achileus obtinuisset, } \\
\text { Dioclitianus ut resistere } \\
\text { his periculis posset, preter } \\
\text { Maximianum, Galerium et } \\
\text { Constantium comitem ma- } \\
\text { gni Constantini patrem Ce- } \\
\text { sares creauit... }\end{array}$ & $\begin{array}{l}\text { Dioclitianus Dalmatheus. } \\
\text { 6.1.30 Ro. Imperator anno } \\
\text { so } 265 \text { Olympiadis Augus- } \\
\text { tus declaratus imperauit } \\
\text { annis.20. Vir certe probus } \\
\text { atque prudens, qui filius apud } \\
\text { Salonem nunc Spalatum Dal- } \\
\text { macie urbem ex patre Scriba } \\
\text { natus hoc anno ex populi, } \\
\text { Senatusque ac Militum om- } \\
\text { nium consensu imperator } \\
\text { electus statim Aprum quem- } \\
\text { dam uirum audacissimum } \\
\text { qui Numerianum Augus- } \\
\text { tum interfecerat manu pro- } \\
\text { pria interfecit. Verum post } \\
\text { aliquot menses cum multa } \\
\text { prospere gessisset bella, im- } \\
\text { minentibus sibi multis bel- } \\
\text { lorum turbinibus quibus } \\
\text { solus resistere non ualebat } \\
\text { Maximianum cognomento } \\
\text { herculeum Cesarem primo, } \\
\text { postea Augustum et im- } \\
\text { perii consortem declarauit, } \\
\text { eo quod agrestes in Gallia } \\
\text { facile compescuit, et pacem } \\
\text { Galliis reddiderit illoque } \\
\text { sibi Socio declarato. Etiam } \\
\text { 4o Imperii sui anno cum } \\
\text { quidam nomine Carausius } \\
\text { sumpta purpura Britanniam } \\
\text { insulam occupasset, et alter } \\
\text { nomine Narseus orienti bel- } \\
\text { lum intulisset, nonnullique } \\
\text { alii Aphricam infestarent, ac } \\
\text { egyptum Achileus obtinuis- } \\
\text { set, Dioclitianus ut resistere } \\
\text { his periculis posset, preter } \\
\text { Maximianum predictum, } \\
\text { Galerium et Constantium } \\
\text { Comitem magni Constantini } \\
\text { patrem Cesares fecit... }\end{array}$ & $\begin{array}{l}\text { Dioclitianus uir obscuris- } \\
\text { sime natus et Dalmatia } \\
\text { oriundus, uir certe probus } \\
\text { atque prudens qui apud } \\
\text { Salonam nunc Spalatum } \\
\text { Dalmatiae urbem ex patre } \\
\text { Scuba [sic]. Hic ex populi } \\
\text { senatusque ac militum om- } \\
\text { nium consensu electus im- } \\
\text { perator. Statim perductum } \\
\text { Aprum interfectorem Nu- } \\
\text { meriani manu sua interfecit. } \\
\text { Verum post aliquot menses } \\
\text { cum multa prospere gessis- } \\
\text { set bella, imminendo sibi } \\
\text { multis bellorum turbinibus } \\
\text { quibus solus resistere non } \\
\text { ualebat, MAXIMIANUS } \\
\text { cognomento Herculeum } \\
\text { Caesarem primo, postea Au- } \\
\text { gustum, imperii consortem, } \\
\text { declarauit, et quod agrestes } \\
\text { in Gallia facile oppresserit } \\
\text { et pacem Gallis rediderit il- } \\
\text { loque sibi socio declarato } \\
\text { etiam imperii sui 4o anno. } \\
\text { Cum quidam nomine CA- } \\
\text { RAUSIUS sumpta purpura } \\
\text { Britanniam insulam oc- } \\
\text { cupatus, et alter nomina } \\
\text { NARSEUS orienti bellum } \\
\text { intulisset nonnulli aliique } \\
\text { [sic] Africam infestarent } \\
\text { et Aegyptum ACHILEUS } \\
\text { obtinuisset, Dioclitianus, ut } \\
\text { resistere his periculis possit, } \\
\text { praeter Maximianum prae- } \\
\text { dictum Galerium et Con- } \\
\text { stantium comitem Magni, } \\
\text { Constantini patrem, Cae- } \\
\text { sares fecit. }\end{array}$ \\
\hline
\end{tabular}


As is immediately obvious, the text in the Naples manuscript is virtually identical in content and wording to that found in both editions of Foresti's work, but it is slightly closer to that found in the 1485 version, following it on points of both detail (the location of Salona, e.g.) and style. It is not the case, however, that the Naples manuscript is simply a copy of either version of Foresti's Supplementum in any straightforward sense (which would be difficult to square with the likely date of the manuscript in any case). For example, the passage from Eutropius on Carus, Carinus, and Numerian which we quoted above is not reproduced in the Supplementum, which instead offers this rather flatter summary of their reigns:

(Foresti, Supplementum chronicarum (Brescia, 1485), lib. VIII, anno mundi 5485, f. 173v) Carus Narbonensis. 35. Ro. Imperator. Olympiade. 265. post Probum Augustum Imperium suscipiens, una cum Carino et Numeriano filiis suis Imperauit .2. annis cuius quidem gesta Flaius Vopiscus pulchre descripsit. Hic suscepto Imperio non Improbe illud administrauit set [sic] multa Imperio Romano adiecit. Nam statim collecto exercitu magno in Mesopotamiam accessit et Charram urbem cepit, ideioque in Persas progrediens Senem et Thesiphontem notissimas urbes debellauit. Verum cum castra super Tygrim fluuium posuisset, fulminis ictu mox concidit. Numerianus uero eius filius, poesim et oratoriam Artem calens, et ipse cum Imperare cepisset, Soceri sui fraude statim a militibus occisus est. Carinus autem alter filius probris omnibus inseruiens a Dioclitiano in Dalmatian superatus, et ignominiose interfectus scelerum suorum sic penas luit.

Foresti also has much material on other empires and kingdoms, along with detailed ecclesiastical history, which do not seem to be in the Naples manuscript.

The most interesting result that emerges from a comparison of the two is that the text of the $D V I$ in the Naples manuscript bears precisely the same relationship to Foresti's Supplementum as that we see in the imperial part. This is easily discernible from the passages printed in Barriera, and in Martin's apparatus. For instance, that anecdote about Lucullus discussed above is found in very similar language in Foresti (TABLE 4). 
Foresti, Supplementum chronicarum (Venice, 1483), lib. VII, anno mundi 5137, Part I, f. 108v
Foresti, Supplementum chronicarum (Brescia, 1485), lib. VII, anno mundi $<5>136$ [9136 a misprint], ff. $124 \mathrm{v}-125 \mathrm{r}$

Propter quod lucullus et ipse indignatus sponte ab republica sese abdicauit, et reliquum uite // sue tempus ad litteraturam quietemue contulit, et omnes opes quas bello quesiuerat parum utiliter consumpsit. Nam ad tantas se conuertit delicias, ut inter ornatos regum conuiuas luculli dinumerarentur in primis. Quod quidem in hoc coniicere par est, quod de illo precipuum memorie traditum est.Nam quadam die pompeius et cicero hoc audienties lucullum ex ocio in foro sedentem conuenerunt, et eo ex more salutato, Cicero uolumus inquit o luculli apud te cenare hodie, hac conditione ut nil noui nostri causa parari iubeas. Quod lucullus recusauit sed in posterum diem parari sibi conuiuium postulauit. Illi autem nolle omnino differre, neque aliud secreto familiares ei potestatem aloquendi concedere, post multa uero hanc tamen illi gratiam postremo praestitere, ut illis audientibus uni ex familiaribus domus sue diceret, hodie in apolline cenabitur. Quo audito famuli confestim intellexerunt, quali ornatu quoue sumptu conficiendum esset conuiuium...

\section{Table 4}

Here the relationship between the different versions of Foresti's Supplementum and the Naples manuscript is precisely parallel to the one we saw in the imperial section: closely parallel to both the 1483 and 1485 versions, but slightly nearer to the latter. At other points, the Naples manuscript seems to represent an almost perfect hybrid of the main tradition of the $D V I$ and Foresti (here only in the 1485 version), such as in its additions to the life of Tarquinius Priscus (TABLE 5). 


\begin{tabular}{|c|c|c|}
\hline $\begin{array}{l}\text { De uiris illustribus } \\
\text { VI 8: }\end{array}$ & $\begin{array}{l}\text { Naples, Biblioteca dei } \\
\text { Girolamini, XL (Martin, Les } \\
\text { Hommes illustres, 11-12): }\end{array}$ & $\begin{array}{l}\text { Foresti, Supplementum } \\
\text { chronicarum (Brescia, } \\
\text { 1485), lib. IIII, anno mundi } \\
\text { 4575, 69v: }\end{array}$ \\
\hline $\begin{array}{l}\text { Latinos bello domuit. } \\
\text { Circum Maximum aedi- } \\
\text { ficauit, Ludos Magnos in- } \\
\text { stituit. De Sabinis et Pris- } \\
\text { cis Latinis triumphauit. } \\
\text { Murum lapideum Vrbi } \\
\text { circumdedit. }\end{array}$ & $\begin{array}{l}\text { Latinos bello domuit et in } \\
\text { signum laetitiae Romanis } \\
\text { confestim Circum Maxi- } \\
\text { mum aedicauit. Ludos Mag- } \\
\text { nos instituit. De Sabinis et } \\
\text { Priscis Latinis triumphauit. } \\
\text { Murum lapideum Vrbi cir- } \\
\text { cumdedit. Capitolium erexit } \\
\text { et cloacas in Vrbe fecit. }\end{array}$ & $\begin{array}{l}\text { firmatoque regno Apiolas } \\
\text { latinorum oppidum ui ce- } \\
\text { pit et in signum leticie, ro- } \\
\text { manis confestim ludos in- } \\
\text { stituit indeque urbem mu- } \\
\text { ris ampliauit et capitolium } \\
\text { erexit. Sabinos rebellantes } \\
\text { uicit eisque colatiam ade- } \\
\text { mitm. Belloque in sabinos } \\
\text { perfecto omne latinorum } \\
\text { nomen domuit et cloacas } \\
\text { postea in urbe fecit... }\end{array}$ \\
\hline
\end{tabular}

\section{Table 5}

This correspondence between Foresti and the Naples manuscript is important in relation to the latter's most discussed feature: the number of chapters it contains. The Naples manuscript manages to include more chapters than any other tradition of the DVI both by having more at the end and by supplying additional chapters interspersed throughout. ${ }^{22}$ Where it is possible to investigate them, these also overlap with Foresti. After DVI 32 on Quintus Fabius Rullus, the Naples manuscript adds another chapter on Gaius Fabricius (TABLE 6).

${ }^{32}$ See Sherwin, “Johannes Mansionarius”. 


\begin{tabular}{|c|c|c|}
\hline $\begin{array}{l}\text { Foresti, Supplementum } \\
\text { chronicarum (Venice, 1483), } \\
\text { lib. VII, anno mundi } 4894 \text {, } \\
\text { Part I, f. 90v }\end{array}$ & $\begin{array}{l}\text { Foresti, Supplementum } \\
\text { chronicarum (Brescia, } \\
\text { 1485), lib. VII, anno mundi } \\
\text { 4896, f. } 105 \mathrm{r}\end{array}$ & $\begin{array}{l}\text { Naples, Biblioteca dei } \\
\text { Girolamini, XL (Barriera, } \\
\text { "Il codice XL", } 450= \\
\text { Martin, Les Hommes } \\
\text { illustres, 37-8): }\end{array}$ \\
\hline $\begin{array}{l}\text { Fabricius Romanorum consul } \\
\text { uir sane fidelis continentissimu- } \\
\text { sque .. Quem cum Romani ad } \\
\text { Pyrrhum Epyrotarum regem pro } \\
\text { redimendis captiuis legatum } \\
\text { misissent, sciens illum Pyrrhus } \\
\text { pauperem quartam regni sui } \\
\text { partem, si ad ipsum transiret ei } \\
\text { obtulit. Fabricius autem Pyr- } \\
\text { rhum, eiusque pollicitationem } \\
\text { contempsit, se malle pauperem } \\
\text { in diuite imperio, quam diui- } \\
\text { tem in paupere imperare dicens. } \\
\text { Quam ob causas ingenti admi- } \\
\text { ratione cum teneretur Pyrrhus } \\
\text { legatum misit qui cum romanis } \\
\text { de pace ageret. Interiecto autem } \\
\text { anno dux contra Pyrrhum a Ro- } \\
\text { manis missus est. Quem Pyrrhus } \\
\text { cum tentasset auro in amicitiam } \\
\text { allicere. Fabricius repulit aurum } \\
\text { dicens, Romanos non quaerere } \\
\text { diuitias, sed ut diuitibus impe- } \\
\text { rent. Tunc quoque cum rex \& } \\
\text { Fabricius uicina haberent castra, } \\
\text { Pyrrhi medicus noctu ad Fabri- } \\
\text { cium uenit, promittens ueneno } \\
\text { se Pyrrhum necaturum, si sibi } \\
\text { aliquid polliceretur. Quem mox } \\
\text { uinctum Fabricius subridens ad } \\
\text { Pyrrhum iussit perduci cum doli } \\
\text { denunciatione. Tum rex admi- } \\
\text { ratus ait, Ille est Fabricius qui } \\
\text { difficilius ab honestate quam sol } \\
\text { a cursu suo auerti potest. Praedi- } \\
\text { cabilis plane fuit Fabricii conti- } \\
\text { nentia que non modo inter ciues } \\
\text { suos spectata, sed ipsi quoque } \\
\text { hosti stupori fuit. Ideoque cum } \\
\text { moriens nihil in hereditate pra- } \\
\text { eter famam reliquisset, Senatus } \\
\text { sua liberalitate filiam eius dota- } \\
\text { tam coniugio tradidit. }\end{array}$ & $\begin{array}{l}\text { Fabricius Romanorum consul } \\
\text { uir sane fidelissimus atque conti- } \\
\text { nentissimus ... qui cum Romani } \\
\text { eum ad pyrrhum Epyrotharum } \\
\text { regem pro redimendis captiuis } \\
\text { suis legatum misissent, Pyrrhus } \\
\text { sciens illum esse pauperem, } \\
\text { quartam regni sui partem ei con- } \\
\text { tulit si ad ipsum transiret. Qui } \\
\text { Pyrrhum \& eius pollicitationem } \\
\text { contempsit dicens, se male [sic] } \\
\text { pauperem in diuite imperio, } \\
\text { quam diuitem in paupere impera- } \\
\text { re. Quod audiens Pyrrhus ingenti } \\
\text { admiratione tentus est \& restitutis } \\
\text { capituis confestim legatum misit, } \\
\text { qui cum Romanis de pace ageret. } \\
\text { Interiecto autem anno Fabricius } \\
\text { Dux contra Pyrrhum a Romanis } \\
\text { missus est. Quem cum Pyrrhus } \\
\text { diu auro tentasset in amicitiam } \\
\text { suam allicere Fabricius repulit } \\
\text { aurum dicens, Romanos non } \\
\text { querere diuitias, sed ut diuitibus } \\
\text { imperent. Tunc quoque cum rex } \\
\& \text { Fabricius castra haberent ui- } \\
\text { cina Pyrrhi medicus noctu ad } \\
\text { Fabricium uenit promittens uene- } \\
\text { no se Pyrrhum necaturum si sibi } \\
\text { aliquid polliceretur. Quem mox } \\
\text { uinctum Fabricius ad Pyrrhum } \\
\text { subridens perduci iussit cum doli } \\
\text { denunciatione. Quamobcausam } \\
\text { rex admiratus ait, Ille ipse est } \\
\text { Fabricius qui difficilius ab hone- } \\
\text { state quam sol a cursu suo auer- } \\
\text { ti potest. Praedicabilis namque } \\
\text { inter caetera fuit huius Fabricii } \\
\text { continentia, quae non modo in- } \\
\text { ter ciues suos spectata, sed ipsi } \\
\text { quoque hosti stupori fuit. Ideo- } \\
\text { que moriens nihil in hereditate } \\
\text { praeter famam euWm reliquisse } \\
\text { fertur propter quod Senatus Ro- } \\
\text { manus sua liberalitate eius filiam } \\
\text { dotatam coniugio tradidit. }\end{array}$ & $\begin{array}{l}\text { De C. Fabritio. Fabritius Ro- } \\
\text { manorum consul uir sane fi- } \\
\text { delissimus atque continentis- } \\
\text { simus. Cum Romani eum ad } \\
\text { Pyrrhum Epirotarum regem pro } \\
\text { redimendis captiuis legatum } \\
\text { misissent. Pyrrhus sciens eum } \\
\text { esse pauperem quartam regni } \\
\text { sui partem ei obtulit, si ad eum } \\
\text { transiret. Qui Pyrrhum et eius } \\
\text { promissa contempsit dicens se } \\
\text { malle pauperem in diuite impe- } \\
\text { rio, quam diuitem in paupere: } \\
\text { quod audiens Pyrrhus ingenti } \\
\text { admiratione capus est et resti- } \\
\text { tutis capituis confestim lega- } \\
\text { tos misit qui cum Romanis de } \\
\text { pace agerent. Interiecto autem } \\
\text { anno creatus dux contra Pyr- } \\
\text { rhum: quem cum Pyrrhus diu } \\
\text { auro temptasset in amicitiam } \\
\text { suam allicere. Fabricius repulit } \\
\text { dicens Romanos non quaerere } \\
\text { diuitias sed ut diuitibus impe- } \\
\text { rarent. Tunc quoque cum castra } \\
\text { uicina haberent, Pyrrhi medi- } \\
\text { cus uenit noctu ad Fabritium } \\
\text { promittens se ueneno Pyrrhum } \\
\text { necaturum, si sibi aliquid polli- } \\
\text { ceretur: quem mox uinctum ad } \\
\text { Pyrrhum subridens misit cum } \\
\text { doli denuntiatione. Quare rex } \\
\text { ait: "ille ipse est Fabritius qui } \\
\text { difficilius ab honestate quam } \\
\text { sol a curso suo auerti potest." } \\
\text { Ideoque moriens nihil in ha- } \\
\text { ereditate praeter famam eum } \\
\text { reliquisse fertur: propter quod } \\
\text { senatus eius filiam dotatam co- } \\
\text { niugi tradidit. }\end{array}$ \\
\hline
\end{tabular}

Table 6 
Equally, the 'additional' life of Veturia which we discussed above is not found in the first edition (1483) of Foresti's Supplementum, but is in his augmented editions from 1485 on (Brescia 1485. lib. V, anno mundi 4700, f. 79r):

Veturia itaque Coriolani predicti mater ... quem legatorum maiestas et pontificum reuerentia nequiuerant ipsa $\mathrm{ab}$ ira retraxit ... Ob cuius mulieris beneficium ne ciuitas ingratitudine argueretur ex Senatus consulto ad perpetuam rei memoriam, eo in loco quo hec Veturia filli iram moliuit templum et Ara fortune constructa sunt . . . sancitum est ut mulieribus homines semper assurgerent et in uia eis cederent quod nunc usque apud nobiles seruatur et quia eis liceret uti auro et purpurea ueste, aurisque fibulis et armillis insuper etiam ex eodem senatus consulto eisdem adiectum fuit, quod antea non licebat nec etiam in ciuitate nostra ex statuto licet: possent hereditates consequi quorumcumque parentum...

It follows that the number of chapters in the Naples manuscript is a product of its connection with the material in Foresti, that is to say that its version of the $D V I$ has been expanded from material extraneous to the tradition. Its curious number of chapters, like much else about it, has its origins in the fifteenth century.

If we want to get to the bottom of what the compilation in the Naples manuscript is, then the vital question, it seems, is of the nature of its connection to the Supplementum. Foresti's sources, like almost everything about him, have never been investigated and the relationship that we have seen above does not obviously show in which direction information flowed. The most recent palaeographic analysis of the Naples manuscript, by Carlotta Griffiths, assigned it to the second half of the fifteenth century, precisely the era when Foresti was working on his history, which means there is no easy way to determine priority. ${ }^{33}$ It thus seems possible that Foresti could be the source of the Naples manuscript: he knew, for instance, that Plutarch was the origin of that story about Lucullus and cited him when he introduced it and he was also far from averse to plundering Boccaccio for his own compositions (as we saw with Veturia above). ${ }^{34}$ Conversely, it also seems possible that this curious manuscript was something he used to write his history, which would perhaps explain why the Supplementum is generally fuller than the Naples MS and why not everything in it is to be found in the Supplementum.

A passage which describes the grisly fate of the famously greedy Roman triumvir Crassus might shed further light on the relationship between the

${ }^{33}$ Credited in Tarrant and Reeve, "De Viris Illustribus", 152 n. 20.

${ }^{34}$ Foresti, Supplementum chronicarum, Brescia, 1485, lib. VII, anno mundi $<5>136$, f. 124v: ut Plutarchus scribit. 
Naples manuscript and Foresti. An apocryphal story held that, after his defeat by the Parthians, Crassus's mutilated corpse suffered the indignity of molten gold being poured down his throat: the poetic justice of a man marked by exceptional avarice being made to drink gold was irresistible. In the Naples manuscript, the story is told as follows:

in]satiabilis cupiditatis qui audita Hierosolymitani templi opulentia, quam Pompeius intactam reliquerat, illo diuertit urbemque ingressus templa peruadit et auream trabem et omnes opes abstulit. Hunc Parthi subito prope Charam [sic] ingruentes oppressere sagittis: quo in conflictu plurimi senatores et consulares et praetorii uiri cecidere, et eius filius nomine Crassus iuuenis occisus est, et Crassum persecuti turpiter interfecerunt. Et decisos brachios et caput in ludibrium suae auaritiae circumtulerunt, liquidum aurum per os deicere exclamantes: Aurum sitisti et aurum bibe. ${ }^{35}$

The first part of this anecdote is derived directly from Orosius:

Anno ab urbe condita DCXCVII Crassus in consulatu collega Pompei prouinciam sortitus in Parthos, homo inexplebilis cupiditatis, audita in Hierosolymis templi opulentia, quam Pompeius intactam reliquerat, in Palaestinam deuertit, Hierosolymam adit, templum peruadit, opes diripit. (2.) inde per Mesopotamiam tendens in Parthiam, quacumque iter habuit sociis ciuitatibus auxilia indixit, pretia exegit moxque ut Euphraten transiit, ilico Vagesen, legatum ab Horode rege Parthorum ad se missum, obuium habuit, a quo uehementer increpitus est, cur contra foedus Luculli et Pompei auaritia inductus Euphraten transierit. quamobrem sine mora futurum, ut pro auro Parthico Serico ferro oneraretur. (3.) itaque cum prope Carras uentum esset, Parthi subito ingruentes cum Surena et Silacea praefectis sagittis oppressere Romanos. cecidere ibi plurimi senatores, aliquot etiam consulares et praetorii uiri; Crassus quoque filius Crassi, lectissimus iuuenis, in acie occisus est. praeterea quattuor cohortes cum Vargunteio legato mediis deprehensae campis et interfectae sunt. Surenas rapto equitatu Crassum persequi intendit eumque circumuentum ac frustra conloquium eius petentem interfecit, quamuis uiuum auferre maluisset. ${ }^{36}$

Two details in the Naples manuscript do not come from Orosius: the golden beam and the golden draught. The beam comes from Josephus: Tulit etiam et

${ }^{35}$ The text is taken from Barriera, "Il codice XL", 451. Martin, Les Hommes illustres, 83, does not give this text, erroneously claiming that it is identical to Orosius 6.13.1-3 (M.-P. Arnaud-Lindet, ed., trans., Orose. Histoire contre les païens, 3 vols., Paris: Belles Lettres, 1990-1991). The beginning is imperfect because of the loss of a folio: the first word preserved was satiabilis, which originally must have been insatiabilis, a somewhat different sense.

${ }^{36}$ Historia contra Paganos VI.13.1-3 (M.-P. Arnaud-Lindet, Orose). 
trabem auream. ${ }^{37}$ The drinking of gold is a little more problematic, because while the story is in Florus and Festus, the epigram aurum bibe does not seem to come from any ancient source. ${ }^{38}$ It was widely known in the Middle Ages, however, and of authors whom Foresti might have read, it can be found (i.a.) in the Speculum Morale attributed to Vincent of Beauvais (III.21.3) and the Chronicon civitatis Ianuensis of Iacopo da Varagine (who does not actually name Crassus, but is clearly describing him). ${ }^{39}$ Its origins are obscure, but it seems to occur in a primitive version in the Carolingian commentary (possibly by Remigius of Auxerre) on Bede's Ars metrica, at a point where the sage of Jarrow is discussing a line of Lucan. ${ }^{40}$ This context would suggest an ultimate derivation from a Lucan scholion, but none of the published scholia seem to transmit it. ${ }^{41}$ For our purposes, however, the interesting fact is that Foresti includes neither detail in the 1483 Supplementum, but did add the golden beam to his account in the 1485 version (TABLE 7).

${ }^{37}$ Antiquitates 14.14 (ed. princeps, Josephi Antiquitates. Augsburg: J. Schüßler, 1470. Online at http://aleph.nli.org.il:80/F/?func=direct\&doc_number=001184407\&local_ base $=$ NNLALL., sine pag.).

${ }^{38}$ Florus, Epitome 1.46.10 (E. Malcovati, ed., L. Annaei Flori quae exstant. Rome: Typis Officinae Polygraphicae, 1972); Festus, Breviarium 17 (J. W. Eadie, ed., The Breviarium of Festus: A Critical Edition with Historical Commentary, London: The Athlone Press, 1967, $60)$.

39 Speculum morale, ed. anonymous, Speculi maioris Vincentii Burgundi praesulis Belvacensis ... tomus tertius, Venice: Dominico Nicolini, 1591, f. 194r col. A. Online at http:// www.mdz-nbn-resolving.de/urn/resolver.pl?urn=urn:nbn:de:bvb:12-bsb10149391-0 (the 'II' at the head of the page is a misprint): "legitur et alibi quod eo capto, cum tractarent primo Parthi cum eo, quasi uolentes pacem eius, quod daretur ei de auro quantum dederet eius appetitui sufficere, cum captum Parthi cepereunt, et per os eius aurum liquefactum igne proiecerunt, dicentes: Aurum sitisti, aurum bibe'. Iacopo (G. Monleone, ed., Iacopo da Varagine e la sua Cronaca di Genova dalle origini al MCCXCVII, Rome: Tip. del Senato, 1941, II, 149): 'tunc etiam in avaris iudicibus et rectoribus complebitur quod cuidam alteri dictum fuit, sicut reffert Orosius, qui cum aurum semper sitiret et satiari non posset, tandem ab inimicis captus fuit. illi autem aurum liquefactum et bulliens in os suum miserunt dicentes: "Aurum sitisti, aurum bibe". et sic patet quod avari iudices et rectores in auro liquefacto et bullienti balneabuntur et auro liquefacto et bullienti potabuntur'.

${ }^{40}$ M. H. King, ed., in C. B. Kendall, C. W. Jones, eds., Bedae venerabilis opera. Pars 6: opera didascalia I (CCSL 123a), Turnhout: Brepols, 1975, 116: igitur ei iam capto [sc. Crasso] inludentes in guture eius aurum funderunt, dixerunt ei bibe aurum quod semper amasti.

${ }^{41}$ It is not in the commentaries widely acknowledged to be ancient, the Commenta Bernensia (H. Usener, ed,. Commenta Bernensia, Leipzig: Teubner, 1869) and the Adnotationes super Lucanum (J. Endt, ed., Adnotationes super Lucanum. Leipzig: Teubner, 1909). It also does not seem to be found in Cavajoni (G. A. Cavajoni, ed., Supplementum adnotationum super Lucanum, 3 vols., Milan: Cisalpino-Goliardica, 1979-1990), though since someone seems to have made off with the Bodleian's copy of volume III, we are not totally certain. 
Foresti, Supplementum (Venice, 1483, lib. VII, anno mundi 5148, Part I, 111v):

Crassus Pompei collega et consul post mortem Sabini anno 2o regni Dionysii missus est Syrie preses, ut Parthos rebellantes reprimeret. Hic (teste Orosio libro sexto capitulo 18o) insatiabilis cupiditatis. Qui audita Hierosolimitani templi opulentia, quam Pompeius intactam reliquerat, in palestinam diuertit, Hierosolimam adit, templum peruadit. Opes duorum milium talentorum diripuit. Inde per Mesopotamiam tendens in Parthiam quocunque iter habuit sociis ciuitatibus auxilia indixit, precia exegit, moxque ut Euphratem transit Vacesenem legatum a rege Parthorum ad se missum obuium habuit, a quo uehementer increpitus est, quur contra fedus Luculli et Pompeii auaritia ductus Euphratem transierit. Quamobrem sine mora futurum esse, ut pro Parthico, Serico, ferro oneretur. Itaque cum prope Cara uentum esset, Parthi subito ingruentes cum Syrena et Syllacia prefectis sagittis romanos oppressere. Cecidere ibi plurimi senatores aliquot etiam consulares et praetorii uiri. Crassus quoque Crassi filius lectissimus iuuenis in acie occissus est. Praeterea quattuor cohortes cum legato deprehense interfecte sunt. Syrenas rapto equitatu Crassum persecutus est, eumque circumuentum, ac frustra colloquium eius petentem interfecit. Verum uarie quidem de Crassi morte apud historicos sententie feruntur, quas breuitatis causa omittimus.
Foresti, Supplementum (Brescia, 1485, lib. VII, anno mundi 5148, 126r):

Crassus Romanus Consul pompei collega anno 2o regni Dionysii mortuo Sabino Syrie presidem in locum suum a Senatu Surrogratur, ut maxime Parthos Syrie uicinos rebellantes reprimeret, uir quidem cupidissimus et insatiabilis cupiditatis, qui (ut Josephus lib. 14 testatur) audita hierosolimitani templi opulentia quam pompeius intactam reliquerat illo diuertit, urbemque ingressus templum peruadit et opes duorum milium talentorum abstulit tulit etiam trabem auream uersatilem trecentas minas pensantem. Indeque diuertiens per Mesopotamiam in parthiam peruenit, et in Itinere sociis ciuitatibus auxilia indixit, preciaque exegit, moxque ut Euphratem transit Vacesenem legatum a rege Parthorum ad se missum obuium habuit, a quo uehementer increpatus est, quur contra Luculli et Pompeii fedus auaritia ductus Euphratem transierit. Quamobrem sine mora futurum esse ut pro Parthico auro Syrico, ferro honeretur. Atque ita cum prope Caram uentum esset, Parthi subito ingruentes cum Syrena et Syllacia prefectis suis et eorum exercitu sagittis oppressere Romanos, quo in conflictu plurimi Senatores et aliquot consulares et praetorii uiri cecidere, et eius filius nomine Crassus lectissimus iuuenis occissus est. Quattuor quoque cohortes cum legato deprehense interfecte sunt, his gestis Parthi duce Syrenas rapido equitatu Crassum persecutui sunt, et eum circumuentum turpiter interfecerunt, uerum uarie quidem de huius Crassi morte apud historicos sententie feruntur, quas breuitatis causa omittimus.

\section{Table 7}


Comparison of the Naples MS to the two editions of the Supplementum is instructive. In the 1483 text, Foresti took over a good deal more information from Orosius than is found in the Naples MS and also cited the late-antique historian by name: an interesting insight into his working method. In the 1485 text, he supplemented his basically Orosian account with some details from Josephus (whom he cited in preference to Orosius) and also reworked his prose in an effort to make it more stylish, adding a few facts here and there. In both versions, at the end, where the Naples manuscript has the epigram, Foresti includes a source-critical note: historians differ as to what ultimately happened to Crassus and he has omitted details for the sake of brevity. These facts suggest a complex relationship between the two versions of Foresti's text and the Naples MS, and are capable of supporting a number of interpretations. It is possible that someone read the 1485 version of Foresti, copied out sections of it, and added a nice epigram from another (uncited) source, but it seems rather unlikely. Equally, it is also possible that Foresti found the Naples MS (an independent production), liked what he saw and used it as he revised his Supplementum for publication in 1485, spotting that a crucial detail came from Josephus, but again that seems somewhat implausible. The most satisfactory solution (albeit one not totally without problems) is perhaps that the Naples MS represents materials which Foresti had himself gathered for his history, some of which he chose not to include and some of which he hoped to return to later: a sort of intermediate version of the Supplementum. That would explain the way that the Naples MS so often mimics the stylistic revisions of the 1485 version, or (as with Veturia) includes content omitted in 1483 , which Foresti later included. It would also provide a neat solution to the vexing way in which the Naples MS so often omits to name those texts which are obviously its sources - presumably Foresti trusted himself to remember them. It would also be of a piece with the difference between Foresti's use of Boccaccio's On Famous Women in the Supplementum (1483) and his De plurimis claris selectisque mulieribus (1497), where the earlier text condenses a source which the later work presents in extenso..$^{42}$ Perhaps, when access to the Girolamini is somewhat easier, palaeographical comparison of the Naples manuscript with Foresti's annotations in volumes he owned might verify this. ${ }^{43}$

${ }^{42}$ Foresti published his own De claris selectisque mulieribus in 1497 at Ferrara, mostly plagiarized from Boccacio: see V. Zaccaria, "La fortuna del De mulieribus claris nel secolo XV: Giovanni Sabadino degli Arienti, Iacopo Filippo Foresti, e le loro biografie femminili (1490-1497)", in F. Mazzoni, ed., Il Boccaccio nelle culture letterature nazionali, Florence: Olschki, 1978, 522-32. The chapter on Veturia (G. F. Foresti, De claris selectisque mulieribus. Ferrara 1497, ff. 35r-35v. Online at urn:nbn:de:bvb:12-bsb00067113-6) follows Boccaccio much more closely than the Naples manuscript and the 1492 Supplementum. It is also worth noting that Boccaccio and Foresti's 1485 edition are much closer to each other than to Boccaccio's likely source, Valerius Maximus (Facta et dicta memorabilia 5.2.1a), who, e.g., has no reference to a decree of the senate.

${ }^{43}$ Among the interesting things he owned, we might note the 1480 Milan edition of 


\section{The Oratorianus and the Corpus Aurelianum}

Besides its connection with Foresti, the Naples manuscript has one other curious feature. In DVI 7 on Servius Tullius, it contains an additional achievement of the Roman king (after 7.8): primus namque censum in urbe instituit et omnem urbis lustrauit exercitum et inuenta fuerunt octoginta hominum milia. ${ }^{44}$ At precisely this same point, the manuscripts of the Corpus Aurelianum also add an additional sentence: primus omnium censum ordinauit qui adhuc per orbem terrarum incognitus erat. ${ }^{45}$ This is a pedestrian fact, the wording copied from Eutropius, but it cannot be accidental that it occurs at precisely the same point in the two versions of the $D V I .^{46}$ Unsurprisingly, it is also in Foresti (TABLE 8).

Foresti, Supplementum, (Venice, 1483, lib. V, anno mundi 4619, Part I, ff. $61 v-62 r)$ :
Foresti, Supplementum, (Brescia, 1485, lib. V, anno mundi 4619, f. 74r):

Primus nanque censum in urbe // instituit: rem profecto tanto imperio saluberrimam, et omnem urbis lustrauit exercitum, et inuenta fuerunt octoginta hominum milia

primus namque censum $\mathrm{i}[\mathrm{n}]$ urbe instituit et omnem urbis lustrauit exercitum ubi inuenta fuerunt octoginta hominum milia...

\section{Table 8}

While it stretches credulity to believe that the $C A$ and the Naples manuscript independently added this point, the differences between the two are revealing. The additional detail of the number of Romans is also in Eutropius (albeit in different words and with a more exact number), while the particle namque is only in Foresti and the Naples manuscript. This seems to imply that the census was mentioned in whatever copy of the DVI the Naples manuscript was derived from, but its compiler supplied more information, and the composite later made its way into Foresti verbatim.

Livy (Cambridge MA, Houghton WKR 11.2.5), the 1494 Basel edition of the De scriptoribus ecclesiasticis of Trithemius (Bergamo, Biblioteca Angelo Mai, Inc. 3.170), and the 1481 Venice edition of Diodorus Siculus (Bergamo, Biblioteca Angelo Mai, Inc. 3.200). The Owners of Incunabula database of the Consortium of European Research Libraries provides a convenient list of Foresti's known books: http://data.cerl.org/owners/2982.

${ }^{44}$ Martin, Les Hommes illustres, 13.

45 ibid

${ }^{46}$ 1.7.1, (ed. Santini, Eutropii Breviarium, 4): Primus omnium censum ordinavit qui adhuc per orbem terrarum incognitus erat. Sub eo omnibus in censum delatis habuit capita LXXXIII milia civium Romanorum. 
Similarly, both the $C A$ and the Naples manuscript add at the end of the life of Tarquinius Priscus (DVI 6) regnavit annis XXXVII. ${ }^{47}$ This is also in Foresti, albeit in a different place, at the beginning of the account of that king (Venice 1483, lib. IIII, anno mundi 4581, Part I, f. 58r,): et regnavit annis 37. This brings the Naples manuscript and the text of the $D V I$ in the $C A$ version into closer proximity, and the scale of their correspondence extends beyond these longer supplements to individual readings. Barriera in 1916 and Martin a century later have both provided lists of readings where the Naples manuscript $(\mathrm{z})$ agrees solely with the manuscripts of the $C A(\operatorname{siglum} \mathrm{A}): 48$

\subsection{4 post appellatus add. imperauit annis XXXVIII A XXXVII regnauit annos $\mathrm{z}$ \\ 11.1 sustinuit] solus sustinuit $\mathrm{A} \mathrm{z}$ \\ 36.1 uulsinii] item uulsinia $\mathrm{A} z$ \\ 47.3 post militum add. factus $\mathrm{A} z$ \\ 57.4 erepsissent $\mathrm{A} \mathrm{z}$ \\ 60.1 dictus A z] om. cett. \\ 73.2 avocasset $\mathrm{A} z$ \\ 74.8 coepisset A z}

Since the $C A$ enjoyed no wide circulation, indeed seems to have emerged precisely in the same decades as the Naples manuscript was written, the relationship between them is possibly significant. Of the over 150 manuscripts of the $D V I$ in the seventy-seven chapter version, only one other thus far has been shown to bear any relationship to the $C A$ text. ${ }^{49}$ That manuscript, Baltimore, Walters Art Museum 388, probably fifteenth-century in date and from Italy, shares at least four short supplements with the $C A$ text, as well as a handful of textually significant readings. ${ }^{50}$ The Naples and Baltimore manuscripts do not seem to have any relationship to each other - a conclusion that must be regarded as provisional, since Martin chose not to collate the Baltimore manuscript. Paradoxically, perhaps, the fact that both Foresti's Supplementum and the Naples manuscript seem to be entirely untouched by the influence of Aurelius Victor in their imperial sections (at least insofar as can be judged from the incomplete evidence at our disposal) all but proves that they never had recourse to a full text of the $C A$. At some stage in Italy, before either of our extant manuscripts of the Corpus Aurelianum were copied, it seems likely that a manuscript of the seventy-seven chapter version

${ }^{47}$ See Martin, Les Hommes illustres, 12.

${ }^{48}$ Martin, Les Hommes illustres, xxxix, n. 139, with additions from his apparatus.

${ }^{49}$ The figure is from Festy, "À propos du Corpus Aurelianum", 91.

${ }^{50}$ W. K. Sherwin, "De Viris Illustribus: Two Unexamined MSS in the Walters Art Gallery”, $C W 65.5,1972,145-6$. 
of the $D V I$ circulated, which had been contaminated from the $C A$ text, albeit without the additional chapters at the end. ${ }^{51}$ This is tantalising evidence for the circulation of a lost manuscript of the $C A$ at some earlier stage, probably in Italy.

\section{CONCLUSIONS}

We have shown that the Naples manuscript is not derived from Matoci's copy of the DVI and that the authentic ancient information it does transmit is a product of humanist scholarship, not some survival from late antiquity. It certainly has some relationship to the Supplementum of Foresti. It is hard to say whether it is derived from it, or a source for it, or a product of its composition, but the latter seems most likely. So, we can safely conclude that Matoci's manuscript of the $D V I$ remains the only known evidence for a ninety-eight chapter version from Proca to Cleopatra. Such a text would account for everything transmitted to us in the DVI, but the two extant versions cannot be put together in such a way as to give us something that would match Matoci's description. More work is needed, but, at a minimum, it seems that his copy was probably the origin of the independent transmission of the $D V I$, and might have been a witness to an ancient version from which the $C A$ text was derived. Since we know that the compiler of the $C A$ was happy to tamper with his text at the beginning, it is entirely possible that as he approached the end of Republican history, and saw how much imperial material he had to integrate from Victor, he began to sharply reduce the number of the lives he inserted. The longer eighty-four chapter text of the $D V I$ may paradoxically represent an abbreviation of the original, while the shorter seventy-seven chapter version may simply be a mutilation. At any rate, while the Codex Oratorianus tells us nothing about Matoci's lost manuscript, its possible relationship to the Corpus Aurelianum's version of the De uiris illustribus sheds new light on the transmission and circulation of that collection, and suggests that the dry and pedantic work of unpicking the connections between humanist historical compendia and the textual tradition of Roman historiography may continue to pay dividends.

\footnotetext{
${ }^{51}$ Sherwin, "Johannes Mansionarius", helpfully notes that the additional chapters after Pompey in the Naples manuscript bear no relation to the additional chapters in the $C A$ version, even when they are covering the same personage. Likewise, the life of Cleopatra in Foresti (anno mundi 5150, Lib. VII, I, 110v) bears no relationship to the life of Cleopatra that concludes the $C A$.
} 


\section{APPENDIX}

Table of Correspondences Between Additions in the Naples Manuscript and Foresti
4.13 (Martin, Les Hommes illustres, 10) Foresti, a.m. 4526
8.3 ( Martin 15)
Foresti, a.m. 4649
$15.2($ Martin 21)
Foresti, a.m. 4688
23.10 (Martin 30)
Foresti, a.m. 4847
novum caput post 28 (Martin 34)
Foresti, a.m. 4867
novum caput post 32 (Martin 37)
Foresti, a.m. 4894
58.4 (Martin 62)
Foresti, a.m. 4156
novum caput post 76 (Martin 83)
Foresti, a.m. 5148

We would like to thank Sir Noel Malcolm, Graham Barrett, Sarah Hendriks, Father Jerome Bertram, John Robertson, Felix Waldmann, Alistair Hamilton, and Gigliola Fragnito for their invaluable help in the course of preparing this article, as well as the staff of the IRHT for their kind assistance. We would also like to warmly thank the reviewers for Exemplaria Classica, who provided substantial and insightful comments. 